\title{
Isolation and characterization of the human diacylglycerol kinase gene
}

\author{
Koshi FUJIKAWA, ${ }^{*}$ Shin-ichi IMAI, $\uparrow$ Fumio SAKANE $†$ and Hideo KANOH $† \ddagger$ \\ *Department of Internal Medicine (Section 4) and †Department of Biochemistry, Sapporo Medical College, West-17, South-1 Sapporo 060, Japan
}

The $80 \mathrm{kDa}$ diacylglycerol kinase (DGK) is abundantly expressed in oligodendrocytes and lymphocytes but not to a detectable extent in other cells such as neurons and hepatocytes. As an initial attempt to delineate the mechanism of the transcriptional control of the DGK gene, we have cloned from a human genomic library a $22 \mathrm{~kb}$ genomic fragment. The genomic clone consists of the $5^{\prime}$-flanking region and 17 exons coding for approx. $53 \%$ of the total exons of human DGK, including those encoding EFhand and zinc-finger regions. The translation initiation site is located in the second exon. S1 nuclease mapping and primer extension analysis of the human DGK mRNA identified a major transcription initiation site (position +1 ) at 264 bp upstream from the initiator ATG. In the 5'-flanking sequence we detected a single GC box at -35 but no canonical TATA and CAAT sequences. However, the sequence starting from the cap site
(AGTTCCTGCCA) is very similar to the initiator element that specifies the transcription initiation site of some housekeeping genes. In addition, the $5^{\prime}$-upstream region contains several putative cis-elements. Jurkat and HepG2 cells were transfected with various $5^{\prime}$-deletion mutants of the upstream region fused to the structural gene of chloramphenicol acetyltransferase (CAT). The CAT assay revealed that among constructs containing up to $3.4 \mathrm{~kb}$ of the $5^{\prime}$-flanking region, a fragment of $263 \mathrm{bp}$ from the transcription initiation site contains a basic promoter that is active in both types of cells. Moreover, the region between -263 and -850 contains a negative element that is active in HepG2 but not in Jurkat cells. This negative element may, at least in part, be responsible for the cell type-specific expression of the DGK gene.

\section{INTRODUCTION}

Diacylglycerol kinase (DGK) converts diacylglycerol into phosphatidic acid. The function of this enzyme in the control of glycerolipid synthesis is unknown, but DGK is thought to play an important role in the signal transduction linked to phospholipid turnover [1], in view of the biological activities of both diacylglycerol [2] and phosphatidic acid [3-5]. Biochemical and immunological studies have shown that animal cells contain several DGK isoenzymes [6]. The molecular sizes of the DGKs so far purified to near homogeneity from animal sources are known to be variable: $80 \mathrm{kDa}$ in porcine brain [7] and thymus [8], and in human white blood cells [9], $150 \mathrm{kDa}$ in porcine thymus [8], 110 and $150 \mathrm{kDa}$ in rat brain [10], and 58,75 and $152 \mathrm{kDa}$ in human platelets [11]. Furthermore, previous work has shown the presence of a membrane-bound arachidonoyldiacylglycerol-specific DGK [12,13] and of an isoenzyme exhibiting the same chromatographic behaviour as that of rat brain synapsin I, a basic protein [14]. Although the structural relationships between these different forms of DGK have not been adequately identified, the findings suggest that animal DGK consists of a family of isoenzymes with considerably different properties.

The DGK isoenzyme of approximate molecular mass $80 \mathrm{kDa}$ ( $80 \mathrm{kDa}$ DGK) was the first to be sequenced by the molecular cloning of cDNA libraries from porcine thymus [15] and later from human white blood cells [9]. The sequences of the two DGK homologues are more than $90 \%$ identical and contain interesting functional domains. The function of zinc-finger structures in the DGK sequence remains ambiguous, but EFhand motifs [16] have recently been shown to be the high-affinity calcium binding sites of DGK $[17,18]$. Immunological studies
$[19,20]$ and Northern blotting analysis [9,15,21] previously showed that the $80 \mathrm{kDa}$ DGK has a limited occurrence in animal cells and tissues, being highly expressed in lymphocytes and brain but essentially absent from cells such as hepatocytes and platelets. Moreover, in a recent study in which the rat homologue of $80 \mathrm{kDa}$ DGK was cloned [21], we found by in situ hybridization and immunohistochemistry that, within the brain, the expression of this isoenzyme is confined to oligodendrocytes and is notably absent from neurons. In the developmental stage, both DGK mRNA and protein levels gradually increased after birth and reached a peak 3 weeks later, followed thereafter by a gradual decline [21]. Such a developmental pattern of expression suggested that this enzyme may be involved in the maturation process of myelin sheath.

The cell type-specific and developmental stage-dependent patterns of the expression of $80 \mathrm{kDa}$ DGK clearly indicate the importance of transcriptional control of the DGK gene. As an initial step in delineating the regulatory mechanisms of DGK gene transcription, we report here the isolation of the human DGK genomic clone, identification of the transcription initiation site, determination of a part of the exon/intron structures, and detection of the promoter activity in the $5^{\prime}$-flanking region using transient expression of the transfected DGK-chloramphenicol acetyltransferase (CAT) fusion gene. This is the first study at the genomic level of the enzyme involved in the animal glycerolipid biosynthesis.

\section{MATERIALS AND METHODS \\ Materials}

Restriction enzymes, myeloblastosis virus reverse transcriptase, S1 nuclease, T4 polynucleotide kinase and Klenow fragment of

Abbreviations used: DGK, diacylglycerol kinase; CAT, chloramphenicol acetyltransferase.

$\ddagger$ To whom correspondence should be addressed.

The nucleotide sequence data reported have been submitted to the DDBJ Nucleotide Sequence Database under accession no. D16440. 


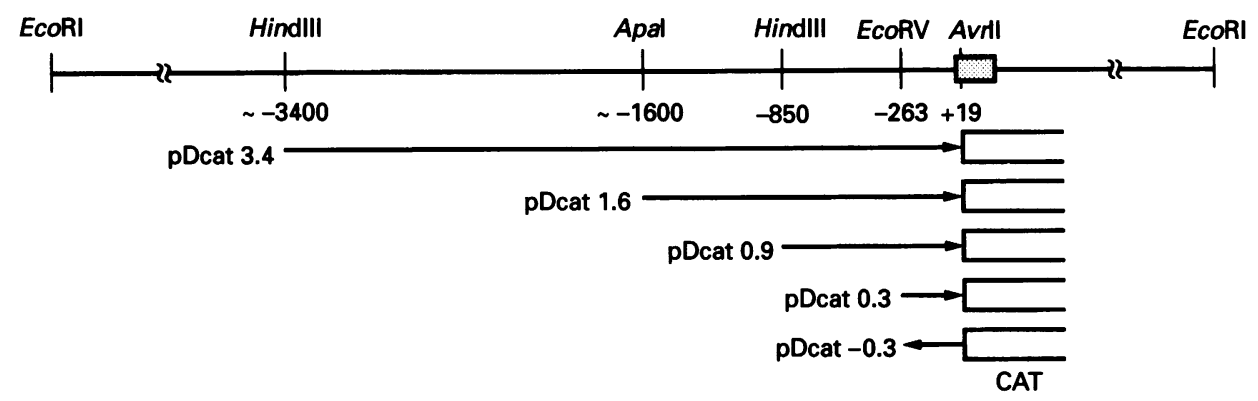

Figure 1 Restriction map of the 5'-end of the human DGK gene and strategy of the construction of DGK-CAT fusion genes

The $5^{\prime}$ sequence of human DGK gene is shown by solid lines, with the CAT gene as an open box. The first exon is shown as a filled box.

DNA polymerase I were purchased from Takara Shuzo Co. (Kyoto, Japan). Acetyl-CoA used for the CAT assay was obtained from Wako Pure Chemicals Co. (Osaka, Japan). $\left[\gamma{ }^{-32}\right.$ P $]$ ATP and $\left[\alpha^{32}\right.$ P $]$ dCTP were bought from Amersham, and $\left[{ }^{14} \mathrm{C}\right]$ chloramphenicol was from du Pont-New England Nuclear. The CAT expression plasmids pUC-CAT [22] and pSV2-CAT [23] were gifts from Dr. K. Fujinaga (Cancer Research Institute, Sapporo Medical College). The $\beta$-galactosidase-containing plasmid pCH110 was obtained from Pharmacia-LKB Biotechnology, Inc., and the lipofectin reagent kit was from Gibco BRL. The DNA sequencing kit was obtained from United States Biochemicals. Oligonucleotides were synthesized using an Applied Biosystems 380B DNA synthesizer. All other chemicals were of the highest quality commercially available.

\section{Isolation and characterization of genomic clones}

General manipulation of DNA was carried out using the standard protocol [24]. A phage EMBL3 library generated by partial digestion of human leucocyte DNA with Sau3AI was kindly donated by Dr. Y. Sakaki (Institute of Medical Science, University of Tokyo). Approx. $5 \times 10^{5}$ plaques were screened by plaque hybridization. Escherichia coli C600 strain was infected with recombinant phage and replica-plated on nitrocellulose filters. The filters were denatured, neutralized, baked at $80^{\circ} \mathrm{C}$ for $2 \mathrm{~h}$, and hybridized with random-primed $\lambda \mathrm{DGK} 1$ clone (2454 bp), which contains nearly the full length of cDNA coding for the porcine DGK (from +38 to +2491 ) [15]. The hybridization was done for overnight at $60^{\circ} \mathrm{C}$ in $3 \times \mathrm{SSC}$ $(1 \times \mathrm{SSC}=0.15 \mathrm{M} \mathrm{NaCl} / 0.015 \mathrm{M}$ sodium citrate $), 10 \times$ Denhardt's solution, $0.1 \%$ SDS and $500 \mu \mathrm{g} / \mathrm{ml}$ salmon sperm DNA. After hybridization, the filters were washed three times in $0.1 \times$ SSC containing $0.1 \%$ SDS for $30 \mathrm{~min}$ at $45^{\circ} \mathrm{C}$, and autoradiographed at $-70^{\circ} \mathrm{C}$ with intensifying screens. Two positive clones were obtained and restriction mapped. The three EcoRI fragments from clone hgDGK4 were subcloned into pBluescript II SK + (Stratagene) for further analysis. A series of fragments was generated by the ExoIII/mung bean nuclease method [25]. The exon-containing fragments were first identified by Southern blotting analysis using the porcine cDNA clones $\lambda$ DGK1 and pDGK23 (358 bp, from -281 to +77$)$ [15] as probes. Exon/intron boundaries were then determined by comparing the sequences of cDNAs of the porcine [15] and human [9] $80 \mathrm{kDa}$ DGKs with that of human genomic DNA, and also by applying the GT/AG rule for the exon/intron border [26]. DNA sequencing of both strands was done by the dideoxy chain- termination method [27] using the M13 universal and reverse sequence primers.

\section{S1 nuclease protection mapping and primer extension}

Total RNA from human thymus (obtained with informed consent from patients undergoing surgical operation for Fallot's tetrad at the College Hospital) was isolated by the guanidine isothiocyanate/CsCl method [28]. The 359 bp EcoRV/XbaI fragment $(-263$ to +96 relative to the transcription initiation site) was ${ }^{32} \mathrm{P}$-labelled using T4 polynucleotide kinase and used as a probe for S1 nuclease mapping. The labelled probe (100000 c.p.m.) and $50 \mu \mathrm{g}$ of the RNA were coprecipitated with ethanol and dissolved in $20 \mu \mathrm{l}$ of the hybridization buffer containing $80 \%(\mathrm{v} / \mathrm{v})$ formamide, $400 \mathrm{mM} \mathrm{NaCl}, 40 \mathrm{mM}$ Pipes (pH 6.4) and $1 \mathrm{mM}$ EDTA. After denaturation at $85^{\circ} \mathrm{C}$ for $10 \mathrm{~min}$, the mixture was incubated at $51^{\circ} \mathrm{C}$ overnight. The mixture was then added to $200 \mu \mathrm{l}$ of the buffer containing $250 \mathrm{mM} \mathrm{NaCl}, 50 \mathrm{mM}$ sodium acetate ( $\mathrm{pH} 4.6$ ), $4.5 \mathrm{mM} \mathrm{ZnSO}_{4}, 100 \mu \mathrm{g}$ of denatured salmon sperm DNA and 60 or 200 units of S1 nuclease. The digestion was done at $37^{\circ} \mathrm{C}$ for $30 \mathrm{~min}$, and the products were analysed on an $8 \mathrm{M}$ urea $/ 6 \%$ polyacrylamide sequencing gel.

For primer extension analysis, a 20-base oligodeoxynucleotide (5'-ATTAAGGCTCTTGGGGTCGC-3') complementary to nucleotides +88 to +69 was synthesized as a primer. After labelling the $5^{\prime}$-end with $\left[\gamma^{-32} \mathrm{P}\right] \mathrm{ATP}$ and T4 polynucleotide kinase, the primer (100000 c.p.m.) and $50 \mu \mathrm{g}$ of the human thymus RNA were coprecipitated with ethanol. The precipitate was dissolved in $20 \mu \mathrm{l}$ of the buffer containing $10 \mathrm{mM}$ Tris $/ \mathrm{HCl}$ (pH 8.3), $300 \mathrm{mM} \mathrm{KCl}$ and $1 \mathrm{mM}$ EDTA. The mixture was denatured at $85^{\circ} \mathrm{C}$ for $10 \mathrm{~min}$, and then allowed to cool slowly to $50^{\circ} \mathrm{C}$. After incubating the mixture for $4 \mathrm{~h}$ at $50^{\circ} \mathrm{C}$, the volume was adjusted to $80 \mu \mathrm{l}$ by the addition of suitable stock solutions to achieve final concentrations of $20 \mathrm{mM}$ Tris/ $\mathrm{HCl}$ (pH 8.3), $10 \mathrm{mM} \mathrm{MgCl}_{2}, 90 \mathrm{mM} \mathrm{KCl}, 10 \mathrm{mM}$ dithiothreitol, $0.25 \mathrm{mM}$ EDTA, $250 \mu \mathrm{M}$ of each dNTP, $100 \mu \mathrm{g} / \mathrm{ml}$ actinomycin $\mathrm{D}$ and 240 units $/ \mathrm{ml}$ avian myeloblastosis virus reverse transcriptase. The reaction was carried out for $2 \mathrm{~h}$ at $42^{\circ} \mathrm{C}$. The extended products were analysed as described in the S1 mapping experiment.

\section{Plasmid construction and CAT assay}

The 5'-flanking region of the DGK gene was isolated from the pBluescript clone, which contained at the EcoRI site an insert of about $5.5 \mathrm{~kb}$ of the $5^{\prime}$-flanking sequence including the first exon 


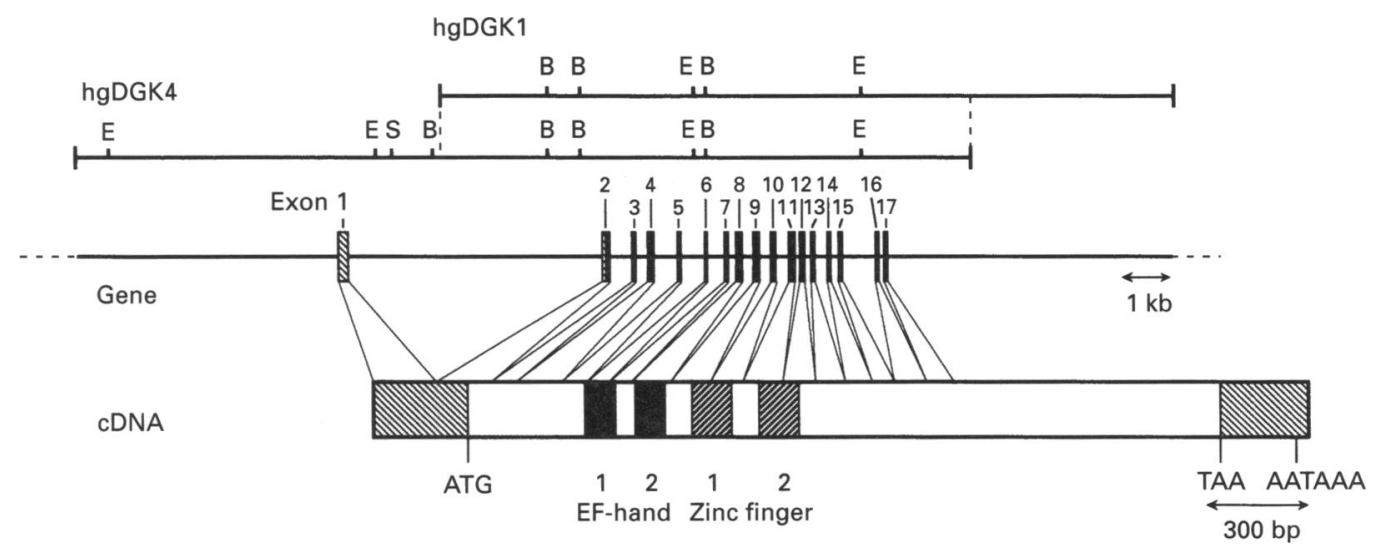

Figure 2 Structural organization and restriction map of portions of the human DGK gene

The restriction map of the two genomic clones of the human DGK gene is shown at the top (E, EcoRI; B, BamHI; S, Sall). The locations of the 17 exons determined by Southern blotting and sequence determination are indicated as the filled boxes, of which non-coding regions are striped. The structure of the human DGK cDNA is schematically shown according to [9].

(Figure 1). The clone was cleaved by ApaI (blunt-ended)/AvrII, HindIII/AvrII and EcoRV/AvrII, yielding respectively fragments of $1.6 \mathrm{~kb}(\sim-1600$ to +19$), 0.9 \mathrm{~kb}(-850$ to +19$)$ and $0.3 \mathrm{~kb}$ $(-263$ to +19$)$. The fragments were inserted into the SalI (blunt-ended)/XbaI or HindIII/XbaI site of pUC-CAT to generate $\mathrm{pDcat} 1.6, \mathrm{pDcat} 0.9$ and $\mathrm{pDcat} 0.3$ respectively. In addition, the $2.5 \mathrm{~kb}$ fragment ( - 3400 to -850 ) was excised by digesting the Bluescript clone with HindIII and inserted into the HindIII site of pDcat 0.9 , thus generating pDcat 3.4. The reverse-oriented pDcat 0.3 (pDcat -0.3 ) was prepared by insertion of a bluntended $0.3 \mathrm{~kb}$ (EcoRV/AvrII) fragment into the blunt-ended SalI/XbaI site of pUC-CAT. pUC-CAT was digested with $S a I I / X b a I$, self-ligated and used as the low-background negative control vector. pSV2-CAT, having the CAT gene under the control of the simian virus 40 early region promoter, was used as the positive control vector.

Prior to DNA transfection, the human T cell line Jurkat and the human hepatoma cell line HepG2 were cultured in RPMI 1640 medium and minimal essential medium respectively, each being supplemented with $10 \%$ fetal bovine serum. Jurkat cells $\left(6 \times 10^{6}\right.$ cells $)$ were transfected with the fusion gene and $\mathrm{pCH} 110$ plasmid ( $5 \mu \mathrm{g}$ of each) using the lipofectin reagent kit according to the manufacturer's instructions. HepG2 cells $\left(2 \times 10^{6}\right.$ cells/ $100 \mathrm{~mm}$ plate) were transfected with the fusion gene and pCH110 (10 $\mu \mathrm{g}$ of each) by the standard calcium phosphate precipitation protocol described by Sambrook et al. [24]. After $48 \mathrm{~h}$, cells were harvested and cellular extracts were assayed for CAT activity as described [23]. The incubation was continued for $6 \mathrm{~h}$ at $37^{\circ} \mathrm{C}$, and the quantification of the CAT activities was achieved by liquid scintillation counting of the acetylated $\left[{ }^{14} \mathrm{C}\right]$ chloramphenicol separated by t.l.c. [24]. The differences in transfection efficiencies were corrected for by assaying the $\beta$ galactosidase activity.

\section{RESULTS}

\section{Isolation and structure of the human DGK gene}

Comparison of the amino acid sequences of the porcine [15] and human [9] homologues of $80 \mathrm{kDa}$ DGK showed that they are more than $90 \%$ identical. We anticipated that the porcine cDNA clones could serve as probes for screening the human genomic library. We thus screened a human EMBL3 genomic library with $a^{32}$ P-labelled $\lambda$ DGK 1 clone coding for nearly the entire length of the porcine DGK cDNA $(+38$ to +2491$)$ [15]. We isolated from $5 \times 10^{5}$ plaques two clones designated hgDGK1 and hgDGK4, spanning 13 and $17 \mathrm{~kb}$ respectively. The two clones were restriction-mapped and were found to overlap. The combined restriction maps are shown in Figure 2. The hgDGK4 clone was selected for further analysis since this clone was hybridized with the porcine pDGK 23 clone (from -281 to +77 ), indicating the presence of the 5 -flanking region. The three EcoRI fragments from hgDGK4 were subcloned into pBluescript II SK +, extensively mapped by restriction enzyme analysis, and the sequences were determined. The exon/intron boundaries were determined by comparing the sequence of the porcine DGK cDNA and the genomic DNA, and also by applying the characteristic GT/AG rule for the nucleotides flanking the exon border [26]. The DNA sequences coding for the human and porcine DGKs are highly similar even in the non-coding region. The 5'-flanking sequences in the first (183 nucleotides) and the second (81 nucleotides) exons were about $80 \%$ identical to the 5 -non-coding sequence determined for the porcine DGK cDNA [15]. Furthermore, the non-coding nucleotide sequence in the second exon and the first five nucleotides in the first exon determined in this work were identical to the human cDNA sequence [9] obtained from the EMBL data bank, thus confirming the exon/intron boundary determined for the two exons. However, the remaining upstream 17-base non-coding nucleotide sequence of the human cDNA was completely different from that of the first exon, for unknown reasons.

The hgDGK 4 clone was found to contain 17 exons ranging in size between 74 and $183 \mathrm{bp}$, as summarized in Table 1 . We could not detect additional exons in the hgDGK 1 clone. The translation initiation site was located at the second exon. The coding region corresponds to about $65 \%$ of the porcine cDNA, and the deduced amino acid sequence (474 residues) was identical to that described for the human cDNA [9]. Based on the size of the human DGK mRNA estimated by Northern blot analysis (3.2 kb) ([9]; and results not shown), the length of the exons determined in the present work $(1687 \mathrm{bp})$ accounts for about $53 \%$ of total exons. The $80 \mathrm{kDa}$ DGK is known to contain functional domains such as EF-hand motifs and zinc fingers in its $\mathrm{N}$-terminal portion $[9,15,21]$. Each of the two zinc fingers is encoded by two exons (exons $9 / 10$ and exons $11 / 12$ ), whereas the 
Table 1 Exon/intron organization of the human DGK gene

Nucleotides in exons are given as capital letters and those in introns as lower-case letters. Codon phases are indicated by boxing.

\begin{tabular}{|c|c|c|c|c|c|c|}
\hline Exon & $3^{\prime}$ acceptor & & $\begin{array}{l}\text { Exon size } \\
\text { (bp) }\end{array}$ & \multicolumn{2}{|c|}{$5^{\prime}$ donor } & $\begin{array}{l}\text { Preceding or } \\
\text { interrupted } \\
\text { amino acid }\end{array}$ \\
\hline 1 & & AGT & 183 & CAG & gtaaag & \\
\hline 2 & gtcacctttccccag & GCC & 145 & $\mathrm{AA} \sqrt{\mathrm{T}}$ & gtgagt & Tyr-22 \\
\hline 3 & ctctctacaccctag & $\overline{\mathrm{ACT}}$ & 74 & GAT & gtgagt & Asp-46 \\
\hline 4 & tcactctcattatag & GCC & 136 & $A \overline{\underline{G}}$ & gtatgg & Asp-92 \\
\hline 5 & cttttttgtaaccag & $\overline{\mathrm{ATT} G}$ & 75 & $\operatorname{AA} \sqrt{T}$ & $\overline{g t g a g t}$ & Phe-117 \\
\hline 6 & taaacaccccaca & $\overline{\overline{I C A}}$ & 50 & TCA & gtgagt & Ser-133 \\
\hline 7 & cccttttgctccag & GAA & 75 & $\mathrm{CCG}$ & gtaagg & Pro-158 \\
\hline 8 & ccactctgtgctca $\overrightarrow{a g}$ & ATT & 120 & ATG & gtgagt & Met-198 \\
\hline 9 & tctcatgcetcctag & $\mathrm{ACC}$ & 115 & $A \Phi \bar{C}$ & gtagta & Leu-237 \\
\hline 10 & ttccttctccetcag & TdT & 89 & GGT & gtgagt & âly-266 \\
\hline 11 & gcctttctcccca $\overline{a g}$ & GTC & 120 & $\mathrm{GAG}$ & gtcagt & Glu-306 \\
\hline 12 & cacctcgtctttca & ATC & 99 & CTG & gtgaga & Leu-339 \\
\hline 13 & tctagcectcccca & $\mathrm{GCC}$ & 84 & $\mathrm{CGG}$ & gtacag & Arg-367 \\
\hline 14 & cttcccccatgc $\overline{a g}$ & ATT & 74 & $\sqrt{\underline{A G}}$ & gtgagg & Arg-392 \\
\hline 15 & ttttcccacacacag & GGT & 75 & $A \underline{G G}$ & gtgagc & Gly-417 \\
\hline 16 & tcccctttgtctcag & $\mathrm{G} \mathrm{CT}$ & 86 & $\operatorname{TTSG}$ & gtagtg & Asp-446 \\
\hline 17 & cacctgcctccgcaq & $\mathrm{AdA}$ & 87 & GA & gtaagt & Gly-474 \\
\hline
\end{tabular}

(a)

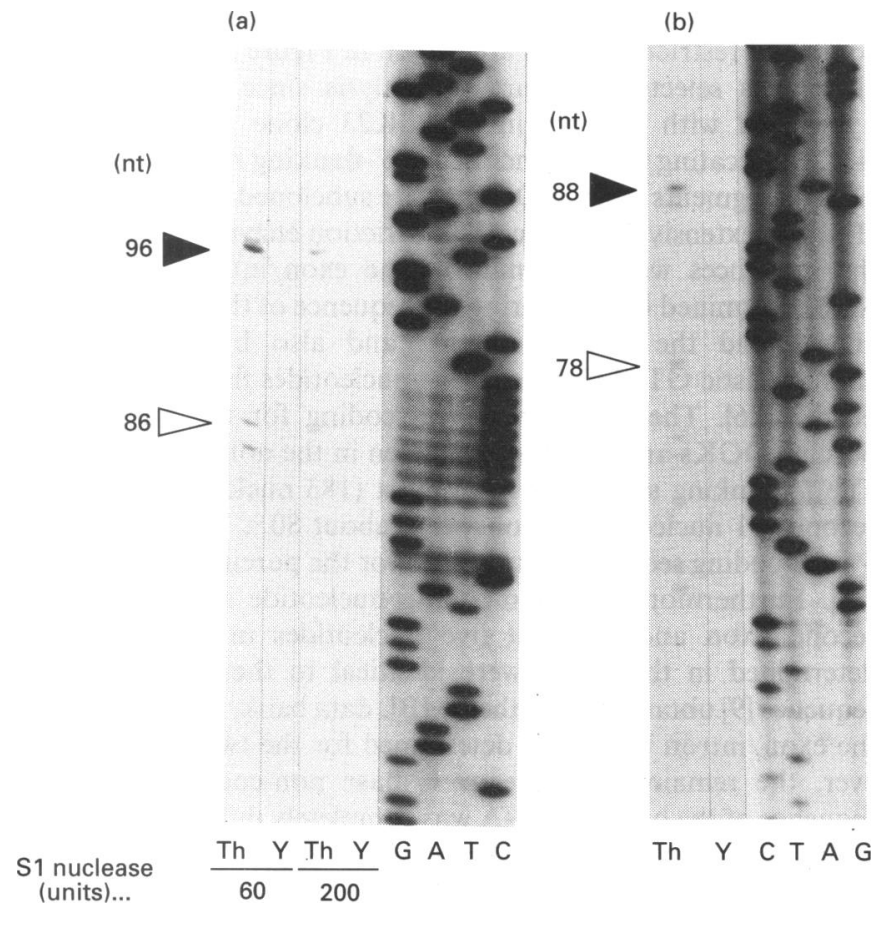

Figure 3 Determination of the transcription initiation site of the human DGK gene

(a) S1 nuclease mapping. Total human thymus RNA (Th) or yeast tRNA ( $Y$ ) was hybridized to the $5^{\prime}$-end labelled S1 probe $(-263$ to +96$)$ and digested with 60 or 200 units of S1 nuclease, as indicated. The size of the protected bands was determined using a sequencing ladder generated using M13 primer and pBluescript II SK +. (b) Primer-extension analysis. Total human thymus RNA (Th) or yeast tRNA ( $($ ) was hybridized to an end-labelled 20-mer antisense oligonucleotide beginning 88 nucleotides downstream from the transcription initiation site shown in Figure 4 . The lengths of the extension products were determined by electrophoresis on a sequencing gel with a sequence ladder, which was generated using the same oligonucleotide primer and the DGK gene (EcoRV/Xbal fragment) as a template. first EF-hand motif is encoded by three exons (exons 5-7) and the second by a single exon (exon 8 ) (Figure 2).

\section{Determination of the transcription initiation site}

To identify the transcription initiation site, we first performed S1 nuclease mapping analysis using a probe $(-263$ to $+96 \mathrm{bp})$ excised from the hgDGK4 clone by $E c o R V / X b a I$ treatment. A major 96-nucleotide fragment was protected by the human thymus mRNA but not by yeast RNA (Figure 3a). Two minor bands of 86 and 84 nucleotides were also protected when treated with the lower concentration of S1 nuclease. To confirm the results obtained from $S 1$ nuclease mapping analysis, we next carried out primer extension analysis. In this case, a 20-mer synthetic oligonucleotide encoding the anti-strand sequence from positions +88 to +69 was used as a primer. One major elongation product extending to position +1 was detected (Figure $3 \mathrm{~b}$ ). Of the two minor fragments detected in the S1 nuclease mapping analysis, the 86-nucleotide band may be significant since a minor extension product at +11 was also detected. Other minor extension products were considered insignificant in view of the results of S1 mapping analysis. The results obtained by $\mathrm{S} 1$ nuclease mapping and primer extension analyses indicated the same major transcription initiation site. We, therefore, concluded that the transcription initiation site is the A residue located 264 bp upstream of ATG, which is located in the second exon. However, we also found evidence for the presence of a minor initiation site at position +11 .

The nucleotide sequence of the 5 -flanking region of the cap site, the first exon and a part of the second exon is presented in Figure 4. In the 5'-flanking region, we did not find the canonical TATA and CAAT boxes at their usual locations relative to the transcription initiation site. There are two TATA-like sequences at -200 (TATATAT) and -334 (TATATTT), but they are considered to be non-functional because of their unusual location. We noted, however, the presence of a GC box at -35 (GGGGCGGGG). Furthermore, the sequence starting from the cap site, AGTTCCTGCCA, is very similar, with one mismatch 
-750 ttgctcgtgtcacccaggctggagtgcagtggcatgctctcggctcactgcaacctctgcctcccaggttcaagcgattctcctgcctcagcctcgcag

650 aactgggactacaggcatgtgcaccacgcccggctaattttttgtatttttagtagagacaggttttcaccgtgttago caggatgtctcaatctcctg

-550 tctcgtgatccgcctgcctcagcctgccaaagtgctgggattacagtgtgagccacegcgcceggcotttggccettgtctttttatgattgggggtga

-450 agggtgagacttggaggggcacaggagcagagagacagaccctctgcaacctatgaccccgaaatctccagtttggatacaacaacaatactcccaag

-350 cctattactcagcagctatattĐctggcaaatgtggaggagtctgttccaacaagcctgtcttgaaacaatcaagaactgcttagatatccctgttccc

-250 ctagaggccetcatgtattcattccctttccaaccccaccaaaagtatgtatatattatgtgtgtgtatgtatgcatacacaataccacacatgcat

-150 tctccctccccttcttcccaccccaggtgtaagaaggacgattccaggaacctaaggetttgttactctgcccattttcaatgaagggtaggagg

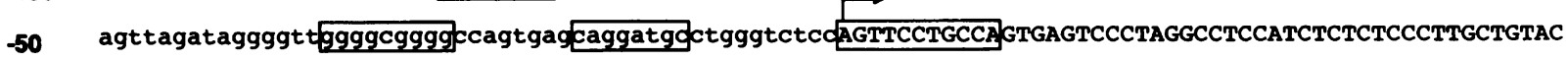

51 ACCTTCACCACCATCCATGCGACCCCAAGAGCCTTAATGACTCTAGAAGAGACTCCAGGCAGGGAAGCTGAAAGACCTTTCACTCCCTACTTTTGGC

151 AGGGCCTCTGTGCCACCTGCCAAGACCAGCAGgtaaagtgg $\cdots-5.1 \mathrm{~kb} \cdots$ ctttccccagGCCTACCCTCTGAAGAGGTCCAAGCAACGGAAG

218

ACTACTACGAAGCTGCCTTTCTGGCATCCTTGAGAAAAATAGACAGATE...

Figure 4 Nucleotide sequence of the 5'-flanking region of the human DGK gene including exons 1 and 2

The nucleotide sequence of the $5^{\prime}$-flanking region and a part of the first intron is presented as lower-case letters, and nucleotides of exons are given as capital letters. Bases are numbered (indicated on the left of the sequence) with respect to the major transcription start site (designated +1 ), which is marked with an arrow. The initiator ATG codon in the second exon is shown in bold. Putative regulatory elements are boxed and include the binding sites for HIP1 (housekeeping initiator protein 1 ) at $+1, \mathrm{SP}-1$ at $-35, \mathrm{C}-$ ets oncoprotein at -18 and $-571, \mathrm{AP}-2$ at -127, a metal responsive element at -494 , and TATA-like sequences at -200 and -334 . A stretch of 28 T residues starting at -789 is underlined.

(underlined), to the initiator element (ATTTCN ${ }_{1-30}$ GCCA) that defines the transcription initiation site of several housekeeping genes, such as the dihydrofolate reductase gene [29,30]. There are several consensus sequences, each with a one-base mismatch indicated by the underlining: a metal responsive element (CGCGCCCGGCC) [31] at -494 , an AP-2 binding site (CCCCAGGT) [32] at -127 , and two binding sites (at -18 and -571) for c-Ets-1 oncoprotein (CAGGATGC/T) [33]. We also noted a long stretch of $28 \mathrm{~T}$ residues starting at -789 .

\section{Promoter activity of the $\mathbf{5}^{\prime}$-filanking region}

In order to see whether the 5 -flanking region contained a functionally active promoter, we constructed various CAT expression plasmids containing fragments ranging from 0.3 to $3.4 \mathrm{~kb}$ of the $5^{\prime}$-upstream sequences, with a constant $3^{\prime}$-end at position +19 . The CAT constructs were transfected to Jurkat T cells, which have been known to express a high level of DGK mRNA ([9]; and results not shown) as well as of enzyme protein [20]. As shown in Figure 5(a), pDcat 0.3, which contains 263 bp of the 5 -flanking region, showed promoter activity. On the other hand, the same flanking region ligated in the reverse orientation relative to the CAT gene (pDcat -0.3 ) gave only background activity. The ligation of constructs containing nucleotides further upstream of the 5 -flanking region, up to $3.4 \mathrm{~kb}$, did not considerably affect the CAT activity. The results show that a basic promoter activity can be expressed by the first $263 \mathrm{bp}$ of the 5 -flanking sequence. In the next experiment, the fusion genes were transfected to HepG2 cells (Figure 5b), which do not contain detectable levels of DGK mRNA or enzyme protein. pDcat 0.3 showed a promoter activity in this cell line also, suggesting that the promoter is not cell type-specific. However, in contrast to Jurkat cells, the constructs containing longer inserts produced a markedly reduced level of in vitro CAT activity in HepG2 cells, as summarized in Figure 5(c). The results suggest that the region between -263 and -850 contains a negative element that is active in HepG2 cells but not in Jurkat cells.

\section{DISCUSSION}

Among the various DGK isoenzymes so far characterized, the mRNA and enzyme protein of $80 \mathrm{kDa}$ DGK are known to be highly abundant in lymphocytes and oligodendrocytes, but are not detectable in other types of cells such as neurons, hepatocytes and platelets. Furthermore, the expression of this enzyme is subject to developmental control in rat brain [21]. The characterization of the genomic structure is essential for understanding such cell-specific and development-dependent patterns of expression of this enzyme. It may be also of interest to determine the exon/intron structures of the gene encoding EFhand motifs and zinc fingers, both of which are highly conserved in a variety of other proteins. Such knowledge may provide a clue as to the evolutionary relationships among the widely conserved domains.

In the present study, we have cloned and characterized the $5^{\prime}$ flanking region and a part of exon/intron structures which correspond to approx. $53 \%$ of the total length of the human DGK cDNA. The 5'-flanking region lacks the canonical TATA and CAAT boxes within $100 \mathrm{bp}$ upstream of the transcription initiation site. The absence of TATA and CAAT boxes at their usual positions relative to the cap site indicates that the DGK gene is a housekeeping gene, in spite of its markedly cell-specific expression. In many housekeeping genes without TATA and CAAT boxes, transcription starts at multiple sites [34]. However, the DGK gene appears to have a single major transcription start site at $264 \mathrm{bp}$ upstream from ATG (approx. $5.3 \mathrm{~kb}$ upstream on the gene), although there was also a possible minor transcription start site at position +11 . Among the housekeeping genes, the genes encoding dihydrofolate reductase and several other proteins have the initiator element (ATTTCN ${ }_{1-30}$ GCCA) at the site of transcription initiation [29,30]. The combination of at least one GC box and this initiator element is sufficient for specifying the transcription initiation site of such housekeeping genes [30]. It is likely that the cap site sequence of the human DGK gene from position + 1 (AGTTCCTGCCA) in com- 
(a)

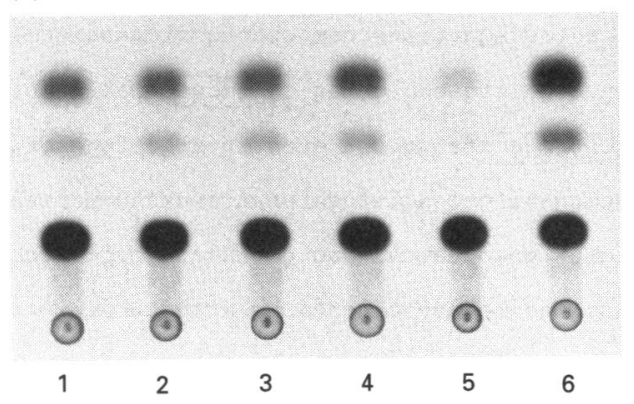

(b)

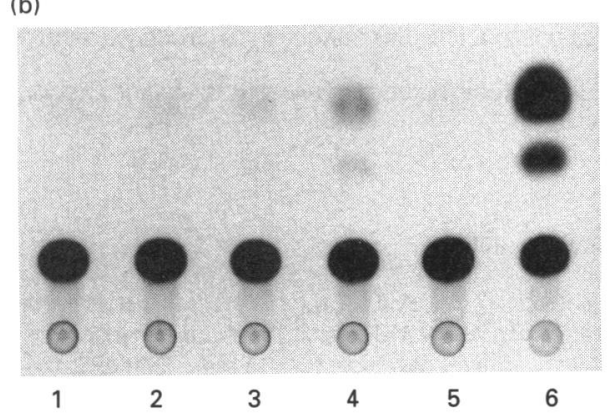

(c)

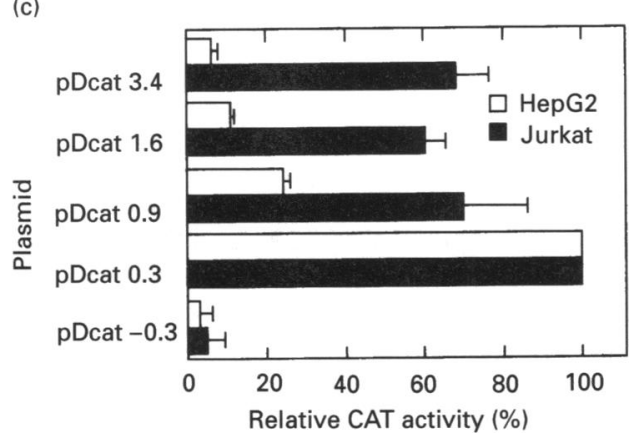

Figure 5 CAT activity in the extracts of Jurkat and HepG2 cells transfected with the fusion gene

Jurkat (a) and HepG2 (b) cells were transfected with the fusion gene constructs by lipofection and calcium phosphate precipitation methods respectively. After $48 \mathrm{~h}$ cells were harvested and, after normalization for $\beta$-galactosidase activity, assayed for CAT activity. The result is a representative CAT assay from three repeated transfections. Lane 1 , pDcat 3.4; lane 2, pDcat 1.6; lane 3, pDcat 0.9 ; lane 4, pDcat 0.3 ; lane 5, pDcat -0.3 ; lane $6, \mathrm{pSV} 2$-CAT (positive control). (c) Following quantification for acetylation of chloramphenicol, the activity with pDcat 0.3 was arbitrarily designated $100 \%$, and relative activity is presented for both cell lines. The results are means $\pm S . D$. from three independent transfections for each cell line.

bination with a single GC box at -35 bp accounts for transcription initiation at a single major site.

The promoter activity of the 5 '-flanking region was established by measuring transient expression of a fusion CAT reporter gene transfected to Jurkat and HepG2 cells. In Jurkat cells, which are known to contain a high level of the DGK mRNA [9], the 5'flanking sequence corresponding to -263 to +19 had a distinct promoter activity in the in vitro CAT assay. This flanking region showed promoter activity even when transfected to HepG 2 cells, which contained no detectable DGK mRNA in Northern blot analysis (results not shown). However, we detected the presence of a negative cis-element(s) that can be involved in the suppression of gene transcription in hepatocytes. This negative element does not appear to be active in Jurkat cells (Figure 5c), thus suggesting a mechanism which allows the efficient transcription of this gene in lymphocytes. It is not clear at the present stage whether cells expressing abundantly the DGK gene contain transcriptional factors which interact with the cis-elements of this gene. There remains a possibility that, in addition to the promoter activity and the negative element(s) we detected, positive cis-elements are required to achieve the cell type-specific expression of the DGK gene. However, the 5 -flanking region of the DGK gene does not appear to possess such positive cis-elements, since upstream $5^{\prime}$ sequence up to $-3.4 \mathrm{~kb}$ did not significantly affect in vitro CAT activity in Jurkat cells. It is therefore possible that the DNA elements conferring the cell type-specific positive regulatory activity may be located in the further $3^{\prime}$-downstream sequence of this gene, which includes the first intron, spanning approx. $5.1 \mathrm{~kb}$. Such a location of regulatory elements is unusual but has been described for several genes, including those encoding platelet-derived growth factor [35], collagen II [36], 6-phosphofructo-2-kinase/fructose-2,6-bisphosphatase [37] and others. In any case, further studies are required to fully account for the cellspecific expression of the DGK gene.

We determined the sequence of exon/intron boundaries which correspond to the $\mathrm{N}$-terminal 474 residues of human DGK. The positions of introns in the EF-hand motifs are completely different from those found in genes coding for EF-hands of calmodulin [38] and calcium-dependent neutral proteinase [39]. This may suggest that the evolutionary origin of EF-hands of DGK may be different from that of other EF-hand-type calcium binding proteins. The basic structure of the zinc fingers in DGK is conserved in several proteins, such as protein kinase $C$ [40], $n$ chimaerin [41] and the vav proto-oncogene product [42]. The two fingers of DGK are each encoded by two exons (exons $9 / 10$ and exons 11/12). The positions of introns are between Asn-236 and Leu-237, and between Glu-306 and Ile-307, in the first and second fingers respectively. The evolutionary significance of these intron/exon positions awaits genomic analysis of other related zinc-finger proteins.

This work was supported in part by Grants-in-Aid for Scientific Research from the Ministry of Education, Science and Culture of Japan, the Uehara Foundation, the Meij Institute of Health Sciences, and the Mochida Memorial Foundation for Medical and Pharmaceutical Research.

\section{REFERENCES}

1 Kanoh, H., Yamada, K. and Sakane, F. (1990) Trends Biochem. Sci. 15, 47-50

2 Nishizuka, Y. (1984) Nature (London) 308, 693-698

3 Yu, C.-L., Tsai, M.-H. and Stacey, D. W. (1988) Cell 52, 63-71

4 Tsai, M.-H., Yu, C.-L. and Stacey, D. W. (1989) Science 243, 522-525

5 Moritz, A., DeGraan, P. N. E., Gispen, W. H. and Wirt, K. W. A. (1992) J. Biol. Chem. 267, 7207-7210

6 Kanoh, H., Sakane, F. and Yamada, K. (1992) Methods Enzymol. 209, 162-172

7 Kanoh, H., Kondoh, H. and Ono, T. (1983) J. Biol. Chem. 258, 1767-1774

8 Sakane, F., Yamada, K. and Kanoh, H. (1989) FEBS Lett. 255, 409-413

9 Schaap, D., de Widt, J., van der Wal, J., Vandekerckhove, J., van Damme, J., Gussow, D., Ploegh, H. L., van Blitterswijk, W. J. and van der Bend, R. L. (1990) FEBS Lett. 275, 151-158

10 Kato, M. and Takenawa, T. (1990) J. Biol. Chem. 265, 794-800

11 Yada, Y., Ozeki, T., Kanoh, H. and Nozawa, Y. (1990) J. Biol. Chem. 265, 19237-19243

12 MacDonald, M. L., Mack, K. F., Williams, B. W., King, W. C. and Glomset, J. A. (1988) J. Biol. Chem. 263, 1584-1592

13 Lemaitre, R. N., King, W. C., MacDonald, M. L. and Glomset, J. A. (1990) Biochem. J. 266, 291-299

14 Kahn, D. W. and Besterman, J. M. (1991) Proc. Natl. Acad. Sci. U.S.A. 88, $6137-6141$

15 Sakane, F., Yamada, K., Kanoh, H., Yokoyama, C. and Tanabe, T. (1990) Nature (London) 344, 345-348

16 Kretsinger, R. H. (1979) Adv. Cyclic Nucleotide Res. 11, 1-26 
17 Sakane, F., Yamada, K., Imai, S. and Kanoh, H. (1991) J. Biol. Chem. 266 7096-7100

18 Sakane, F., Imai, S., Yamada, K. and Kanoh, H. (1991) Biochem. Biophys. Res. Commun. 181, 1015-1021

19 Yamada, K. and Kanoh, H. (1988) Biochem. J. 255, 601-608

20 Yamada, K., Sakane, F. and Kanoh, H. (1989) FEBS Lett. 244, 402-406

21 Goto, K., Watanabe, M., Kondo, H., Yuasa, H., Sakane, F. and Kanoh, H. (1992) Mol. Brain Res. 16, 75-87

22 Gilman, M. Z., Wilson, R. N. and Weinberg, R. A. (1986) Mol. Cell. Biol. 6, 4305-4316

23 Gorman, C. M., Moffat, L. F. and Howard, B. H. (1982) Mol. Cell. Biol. 2, 1044-1051

24 Sambrook, J., Fritsch, E. F. and Maniatis, T. (1989) Molecular Cloning: A Laboratory Manual, 2nd edn., Cold Spring Harbor Laboratory Press, Cold Spring Harbor, NY

25 Yanisch-Perron, C., Vieira, J. and Messing, J. (1985) Gene 33, 103-119

26 Mount, S. M. (1982) Nucleic Acids Res. 10, 459-472

27 Sanger, F., Nicklen, S. and Coulson, A. R. (1977) Proc. Natl. Acad. Sci. U.S.A. 74, 5463-5467

28 Chirgwin, J. M., Przybyla, A. E., MacDonald, R. J. and Rutter, W. J. (1979) Biochemistry 18, 5294-5299

29 Chen, M.-J., Shimada, T., Moulton, A. D., Cline, A., Humphries, R. K., Maizel, J. and Nienhuis, A. W. (1984) J. Biol. Chem. 259, 3933-3943
30 Means, A. L. and Farnham, P. J. (1990) Mol. Cell. Biol. 10, 653-661

31 Karin, M., Haslinger, A., Heguy, A., Dietlin, T. and Cooke, T. (1987) Mol. Cell. Biol. 7, 606-613

32 Imagawa, M., Chiu, R. and Karin, M. (1987) Cell 51, 251-260

33 Wasylyk, C., Gutman, A., Nicholson, R. and Wasylyk, B. (1991) EMBO J. 10, $1127-1134$

34 Martini, G., Toniolo, D., Vulliamy, T., Luzzato, L., Dono, R., Vigleitto, G., Pronessa, G., D'Urso, M. and Persico, M. G. (1986) EMBO J. 5. 1849-1855

35 Franklin, G. C., Donovan, M., Adam, G. I. R., Holmgren, L., Pfeifer-Ohlsson, S. and Ohlsson, R. (1991) EMBO J. 10, 1365-1373

36 Horton, W., Miyashita, T., Kohno, K., Hassel, J. R. and Yamada, Y. (1987) Proc. Natl. Acad. Sci. U.S.A. 84, 8864-8868

37 Lange, A. J., Espinet, C., Hall, R., El-Maghrabi, M. R., Vargas, A. M., Miksicek, R. J., Granner, D. K. and Pilkis, S. J. (1992) J. Biol. Chem. 267, 15673-15680

38 Nojima, H. and Sokabe, H. (1987) J. Mol. Biol. 193, 439-445

39 Emori, Y., Ohno, S., Tobita, M. and Suzuki, K. (1986) FEBS Lett. 194, 249-252

40 Kikkawa, Y., Kishimoto, A. and Nishizuka, Y. (1989) Annu. Rev. Biochem. 58, 31-44

41 Ahmed, S., Kozma, R., Monfries, C., Hall, C., Lim, H. H., Smith, P. and Lim, L. (1990) Biochem. J. 272, 763-773

42 Coppola, J., Bryant, S., Koda, T., Conway, D. and Barbacid, M. (1991) Cell Growth Differ. 2, 95-105

Received 22 February 1993/13 April 1993; accepted 20 April 1993 